\title{
PENGELUARAN PENDIDIKAN BAGI ANAK ANGKAT DI INDONESIA, BENARKAH LEBIH BESAR DARI ANAK KANDUNG?
}

\author{
Rizky Maulana, Universitas Indonesia \\ rizky.maulana82@ui.ac.id \\ Ika Rahma Ginting, Sekolah Tinggi Ilmu Ekonomi Bisnis Indonesia \\ ika.rahma@stiebi.ac.id
}

\begin{abstract}
ABSTRAK
Berkembang stigma di masyarakat bahwa anak kandung lebih disayang dan diunggulkan oleh orang tuanya dibandingkan anak angkat. Oleh karena itu, penelitian ini dilakukan untuk menganalisis perbedaan pengeluaran pendidikan antara anak kandung dan anak angkat di Indonesia. Dengan berbekal data IFLS 5, penelitian ini mengestimasi model penelitian dengan menggunakan metode regresi linear berganda dengan estimasi OLS. Hasil estimasi menunjukkan bahwa anak angkat mendapatkan porsi pengeluaran biaya pendidikan lebih besar dibandingkan anak kandung. Hal ini bertentangan dengan stigma yang berkembang di masyarakat. Ternyata, meskipun anak angkat tidak memiliki hubungan darah dengan orang tua angkatnya, kebutuhan pendidikan mereka ternyata tetap diperhatikan, bahkan dengan pengeluaran yang lebih besar dibandingkan anak kandung.

Kata Kunci: Pengeluaran Pendidikan, Anak Angkat, Karakteristik Orang Tua.
\end{abstract}

\section{ABSTRACT}

Stigma has developed in the community that biological children are more loved and favoured by their parents than adopted children. Therefore, this study conducted to analyze the differences in education expenditure between biological and adopted children in Indonesia. Using IFLS 5 data, this study estimates the research model using multiple linear regression methods with OLS estimation. Estimation results show that adopted children get a higher portion of education expenses than biological children. This matter is contrary to the stigma that develops in society. Even though adopted children do not have natural ties with adoptive parents, their educational needs are still considered, even with higher expenditure than biological children.

Keywords: Education Expenditure, Adopted Children, Parent Characteristics.

\section{PENDAHULUAN}

Berdasarkan teori Engel, semakin tinggi tingkat pendapatan maka persentase pengeluaran rumah tangga untuk konsumsi pangan akan mengalami 
penurunan. Mengacu pada teori tersebut maka keluarga dapat dikatakan sejahtera apabila persentase pengeluaran untuk pangan semakin kecil dibandingkan dengan persentase pengeluaran non-pangan (Widyaningsih \& Muflikhati, 2015). Berdasarkan pengeluaran pendidikan dan kesehatan, rumah tangga Indonesia belum memprioritaskan pengeluarannya untuk investasi modal manusia untuk meningkatkan kualitas hidupnya (Wuryandari, 2015). Tenaga kerja yang produktif dan berkualitas sangat dipengaruhi oleh pendidikan (Maulana, 2020). Oleh karena itu, tingkat pendidikan tenaga kerja digunakan sebagai proksi dari sumber daya manusia yang sering digunakan sebagai indikator kemajuan pertumbuhan di suatu negara. Berkaitan dengan pendidikan, dapat dikatakan bahwa sekolah adalah bentuk investasi, dan spesifikasi dasar dan implikasi lain dari investasi ini merujuk pada apa yang disebut pengembalian dalam pendidikan, biasanya dicerminkan dalam upah yang berbeda karena investasi dalam pendidikan (Reza \& Widodo, 2013). Rata-rata pengeluaran rumah tangga per kapita per bulan untuk makanan setiap tahunnya masih lebih tinggi dibandingkan untuk pengeluaran pendidikan seperti pada gambar 1 .

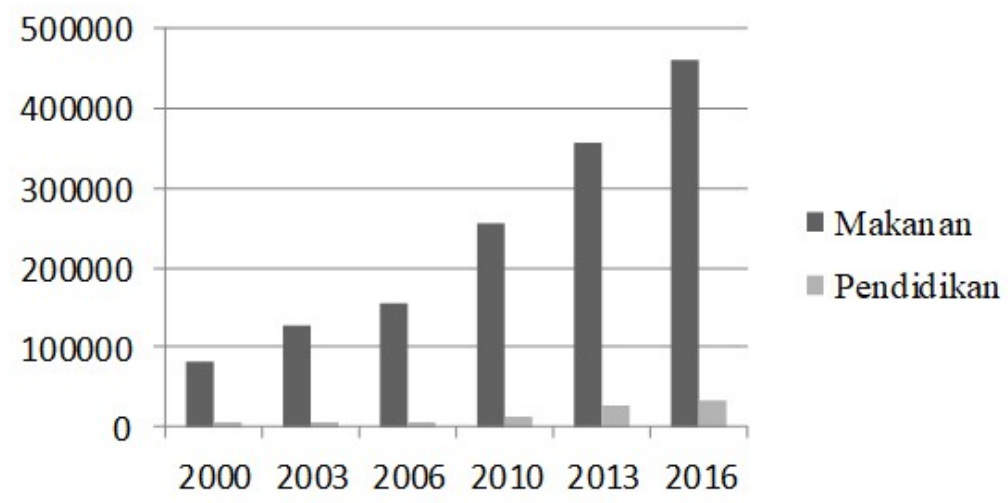

Gambar 1. Pengeluaran Makanan dan Pendidikan

Keputusan sekolah pada rumah tangga ditentukan oleh interaksi faktor sosial, budaya dan ekonomi yang bekerja melalui hubungan kekuasaan di dalam rumah tangga. Seseorang dapat memandang pendidikan, secara konseptual, baik sebagai konsumsi maupun investasi. Orang tua mendidik anak-anak mereka sehingga anak-anak dan cucu-cucu mereka akan memiliki kesempatan hidup yang lebih baik, dan karena mereka menikmati memiliki anak-anak yang terpelajar dan berpendidikan. Orang tua juga berinvestasi pada pendidikan anak-anak mereka, agar anak-anak tersebut mendapat posisi yang baik, dan dapat mendukung orang tua dikemudian hari (Al-Samarrai \& Peasgood, 1998).

Pendekatan fungsi produksi rumah tangga yang dikembangkan oleh Becker (1993) telah banyak digunakan dalam penelitian untuk memodelkan keputusan bersekolah dalam sebuah rumah tangga. Dalam model tersebut tersirat bahwa ada investasi optimal dalam pendidikan untuk setiap anak yang sama dengan nilai bersih sekarang dari manfaat dan biaya yang diharapkan rumah tangga untuk mendidik anak-anak mereka. Yang termasuk dengan biaya langsung adalah biaya yang dikeluarkan selama anak bersekolah dan biaya langsung lainnya, seperti biaya membeli seragam. Biaya tidak langsung 
termasuk biaya peluang dari waktu yang anak-anak habiskan untuk bersekolah, yaitu kegiatan yang tidak bisa dilakukan ketika anak-anak harus bersekolah, seperti membantu orang tua di rumah atau bekerja, dan biaya tidak langsung lainnya, seperti kemungkinan risiko kehamilan pada anak perempuan yang bersekolah. Sedangkan manfaat pendidikan bagi rumah tangga, tergantung dari banyak faktor. Misalnya probabilitas anak-anak akan mendapatkan pekerjaan, peningkatan produktivitas anak-anak tersebut karena peningkatan pendidikan, dan preferensi waktu rumah tangga. Anak perempuan yang mengalami diskriminasi upah, akan mengurangi pengembalian rumah tangga yang diharapkan dari berinvestasi dalam pendidikan. Atau ketika anak perempuan tidak diijikan bekerja karena harus menikah, maka orang tua mungkin tidak dapat memeroleh manfaat dari investasi sekolah anak perempuan mereka (AlSamarrai \& Peasgood, 1998).

Anak adalah seseorang yang belum berusia 18 (delapan belas) tahun, termasuk anak yang masih dalam kandungan (UU RI No.35 Tahun 2014 tentang Perubahan Atas Undang-Undang Nomor 23 Tahun 2002 tentang Perlindungan Anak Pasal 1 ayat (1)). Anak Angkat adalah Anak yang haknya dialihkan dari lingkungan kekuasaan Keluarga Orang Tua, Wali yang sah, atau orang lain yang bertanggung jawab atas perawatan, pendidikan, dan membesarkan Anak tersebut ke dalam lingkungan Keluarga Orang Tua angkatnya berdasarkan putusan atau penetapan pengadilan (UU RI No.35 Tahun 2014 tentang Perubahan Atas Undang-Undang Nomor 23 Tahun 2002 tentang Perlindungan Anak Pasal 1 ayat (9)). Setiap Anak berhak memperoleh pendidikan dan pengajaran dalam rangka pengembangan pribadinya dan tingkat kecerdasannya sesuai dengan minat dan bakat. (UU RI No.35 Tahun 2014 tentang Perubahan Atas Undang-Undang Nomor 23 Tahun 2002 tentang Perlindungan Anak Pasal 9 ayat (1)).

Hubungan antara orang tua dan anak angkat bukan berdasarkan kekerabatan biologis, sehingga penelitian tentang keluarga angkat sangat cocok untuk menyelidiki mekanisme di balik alokasi sumber daya orang tua untuk anak-anak mereka terutama pendidikan. Memahami apa yang mendasari proses investasi orang tua dapat membantu menentukan bagaimana struktur keluarga menguntungkan atau menghambat peluang hidup anak-anak (Hamilton et al., 2007). Penelitian tentang determinan pengeluaran pendidikan oleh rumah tangga sudah banyak dilakukan, tetapi masih jarang yang berfokus pada penelitian determinan pengeluaran pendidikan untuk anak kandung dan angkat, terutama di Indonesia. Stigma yang berkembang di masyarakat adalah anak kandung lebih disayang dan diunggulkan oleh orang tuanya dibandingkan anak angkat. Hal tersebut disebabkan oleh tidak adanya hubungan biologis (biological ties) antara anak dan orang tua. Maka, orang tua angkat mengalami kesulitan untuk merepresentasikan kehadiran mereka sebagai orang tua kandung bagi anak tersebut (Hamilton et al., 2007). Oleh karena itu penelitian ini dilakukan untuk melihat perbedaan pengeluaran pendidikan rumah tangga antara untuk anak kandung dan anak angkat.

Beberapa penelitian terdahulu telah dilakukan terkait melihat hubungan antara status anak terhadap investasi atau pengeluaran orang tua di berbagai sektor. Hamilton et al. (2007) dalam studinya mendapatkan hasil bahwa orang tua justru berinvestasi lebih banyak ke anak angkat. Hal ini juga tidak sesuai 
dengan hipotesisnya yang menduga bahwa orang tua akan lebih banyak berinvestasi pada anak biologisnya. Hasil yang berbeda dikemukakan oleh Liu et al. (2004). Studinya menyatakan bahwa terdapat perbedaan perlakuan antara anak angkat dan anak kandung. Pada hal-hal yang terkait dengan kebutuhan pokok seperti pemenuhan makanan, gizi, dan kesehatan, anak angkat mengalami pemenuhan kebutuhan yang sama seperti anak kandung. Namun, dalam hal pendidikan justru anak kandung memiliki keunggulan dibandingkan anak angkat. Dalam hal prestasi akademik, anak-anak angkat juga tidak kalah baik dibandingkan anak kandung (Raleigh \& Kao, 2013).

Beberapa hasil penelitian tentang determinan pengeluaran rumah tangga terhadap pendidikan berkesimpulan bahwa tingkat pendapatan orang tua meningkatkan pengeluaran pendidikan bagi anak (Acar et al., 2016; Song \& Zhou, 2019). Kepala rumah tangga yang lebih kaya cenderung membelanjakan pendapatannya lebih besar untuk pendidikan dan gizi. Rumah tangga yang berpenghasilan tinggi berinvestasi lebih banyak dalam pendidikan anggota mereka dibandingkan dengan yang berpenghasilan bawah, sementara jumlah investasi pendidikan per rumah tangga adalah fungsi positif dari ukuran rumah tangga tersebut (Iddrisu et al., 2017). Jika rumah tangga yang Kepala Rumah Tangganya memiliki pendidikan tinggi cenderung lebih sejahtera serta pengeluaran pendidikan yang lebih besar dibandingkan KRT yang berpendidikan rendah (SD ke bawah) (Chi \& QIan, 2016; Khalili et al., 2020; Wuryandari, 2015).

Selain karakteristik orang tua, berapa banyak saudara kandung yang dimiliki anak dan urutan kelahirannya dianggap memengaruhi potensi akses anak ke sekolah. Jumlah anak dalam rumah tangga kemungkinan akan mempengaruhi tingkat sumber daya yang tersedia untuk setiap anak secara negatif, melalui kebutuhan untuk berbagi sumber daya secara lebih luas, dan secara positif, melalui potensi anak yang lebih besar untuk memberikan dukungan bagi anak yang lebih muda. Anak-anak dalam rumah tangga juga dapat berbagi beban kerja rumah tangga, dengan peningkatan jumlah anak yang berpotensi mengurangi beban kerja masing-masing individu (Al-Samarrai \& Peasgood, 1998). Ukuran rumah tangga besar berhubungan negatif dengan pengeluaran rumah tangga untuk pendidikan dan gizi (Kousar et al., 2017).

Penelitian ini menggunakan data dari IFLS gelombang 5. Data berbentuk cross-section satu titik waktu yaitu tahun 2014. Sampel yang digunakan adalah siswa Sekolah Dasar di Indonesia. Penelitian ini mengestimasi model dengan metode regresi linear berganda dengan estimasi OLS. Variabel penjelas utama yang digunakan adalah status anak, sedangkan variabel terikatnya adalah besaran pengeluaran biaya pendidikan. Penelitian ini juga menggunakan beberapa variabel kontrol seperti pendapatan orang tua, pendidikan orang tua, usia orang tua, jumlah anggota rumah tangga, status atau jenis sekolah (swasta atau negeri) dan jarak dari rumah ke sekolah. Hasil estimasti menyatakan bahwa anak angkat mendapatkan pengeluaran biaya pendidikan Rp. 2,484,685 lebih besar dibandingkan anak kandung. Variabel pendapatan orang tua juga berpengaruh signifikan, namun hubungannya tidak elastis.

Di Indonesia sendiri masih terdapat beberapa ketidaksesuain pada proses pengangkatan anak. Pengangkatan anak seyogyanya dilakukan melalui lembaga hukum yang memperhatikan prosedur yang berlaku sesuai undang- 
undang (Heriawan, 2017; Mutasir, 2017; Wardah, 2011). Namun, masih banyak calon orang tua angkat yang mengangkat anaknya melalui proses langsung atau tanpa lembaga hukum. Hal ini akan menyebabkan ketidakjelasan pada status hukum anak tersebut (Heriawan, 2017). Selain mengangkat secara langsung, salah satu desa di Indonesia mengangkat anak dengan proses hukum adat yang berlaku disana. Maka, motivasi penduduk desa tersebut untuk mengangkat anak adalah untuk membantunya bekerja di ladang atau menjadi alasan-alasan takhayul yang menganggap anak angkat tersebut sebagai 'pancingan' untuk memiliki anak kandung (Mutasir, 2017).

\section{METODE PENELITIAN}

Untuk menjawab rumusan masalah dan tujuan dari penelitian ini, maka penelitian ini menggunakan metode regresi berganda dengan estimasi Ordinary Least Square (OLS). Penelitian ini menggunakan beberapa variabel bebas. Variabel bebas utama adalah status anak, yaitu variabel dummy yang menunjukkan seorang anak berstatus anak kandung atau anak bukan kandung (angkat). Variabel terikat yang digunakan dalam penelitian ini adalah pengeluaran pendidikan, yaitu seluruh total pengeluaran terkait pendidikan, mulai dari iuran SPP, biaya kebutuhan sekolah, hingga uang saku harian anak. Variabel terikat bersifat kontinu. Selain kedua variabel itu, penelitian ini juga menggunakan beberapa variabel kontrol, yaitu variabel-variabel yang berhubungan dengan karakteristik keluarga dan orang tua, karena pada praktiknya pengeluaran pendidikan ditanggung oleh orang tua. Variabelvariabel yang dimaksud adalah pendapatan orang tua, pendidikan orang tua, usia orang tua, jumlah anggota rumah tangga, dan variabel diluar karakteristik orang tua, seperti status sekolah (negeri/swasta) dan jarak dari rumah ke sekolah.

Tabel 1. Definisi Operasional Variabel

\begin{tabular}{ll}
\hline \multicolumn{1}{c}{ Variabel } & \multicolumn{1}{c}{ Definisi } \\
\hline Pengeluaran pendidikan & Besaran total biaya pendidikan dalam satu tahun ajaran. \\
& Dalam satuan Rupiah. \\
Status anak & Variabel dummy. Bernilai 1 apabila anak berstatus anak \\
& kandung, bernilai 0 jika berstatus anak angkat/adopsi. \\
Pendapatan orang tua & Besaran pendapatan orang tua dalam satu tahun. Dalam \\
& satuan Rupiah. \\
Pendidikan orang tua & Variabel dummy. Bernilai 1 apabila orang tua \\
& berpendidikan tinggi diatas SMA, bernilai 0 jika \\
& pendidikan setara dan dibawah SMA. \\
Usia orang tua & Umur orang tua dalam satuan tahun. \\
Jumlah anggota rumah tangga & Jumlah individu dalam satu rumah tangga. \\
Status sekolah & Variabel dummy. Bernilai 1 apabila sekolah berstatus \\
& neger, bernilai 0 jika sekolah swasta. \\
Jarak ke sekolah & Waktu tempuh dari rumah ke sekolah. Dalam satuan \\
& menit \\
\hline
\end{tabular}

Penelitian ini menggunakan data dari Indonesian Family Life Survey atau IFLS, yaitu survey yang dilakukan oleh lembaga Rand yang berokus pada aspek-aspek kehidupan masyarakat Indonesia seperti pendapatan, pengeluaran, pendidikan, perkawinan, migrasi, ketenagakerjaan, dan lain-lain. Data IFLS 
memiliki unit analisis mikro hingga ke level individu. IFLS adalah survey yang dilakukan setiap tujuh tahun sekali sejak tahun 1993, namun penelitian ini hanya mengambil satu titik waktu, yaitu tahun 2014 yang terdapat pada IFLS gelombang ke-5. Sampel yang digunakan adalah anak usia sekolah. Untuk menyederhanakan model, penelitian ini hanya mengambil anak-anak yang sedang bersekolah pada jenjang sekolah dasar atau SD yang menghasilkan sampel sebesar 3,720 anak.

Status anak angkat dan kandung diambil dari buku K kode AR02b. pengeluaran pendidikan diambil dari buku 5 kode DLA91b. Pendapatan orang tua diambil dari buku K kode AR15b. Pendidikan orang tua diambil dari buku K kode AR16. Usia orang tua diambil dari buku K kode AR09. Jumlah anggota rumah tangga didapatkan dari identitas keluarga yang ditambahkan menurun dengan fungsi 'egen by hhid' pada software STATA. Status sekolah diambil dari buku 5 kode DLA71. Jarak ke sekolah diambil dari buku 5 kode DLA76j.

Adapun definisi operasional dari masing-masing variabel disajikan pada tabel 1. Variabel-variabel tersebut diestimasi dengan persamaan OLS sebagai berikut:

$$
\begin{aligned}
& \text { EDUC_EXP } P_{i}=\beta_{0}+\beta_{1} \text { STATUS }_{i}+\beta_{2} \text { HEAD INCOME }_{i}+ \\
& \beta_{3} H E A D_{-} E D U C_{i}+\beta_{4} H E A D \_A G E_{i}+\beta_{5} J A R T_{i}+\beta_{6} S C H O O L_{i}+\beta_{7} D_{I S T A N C E} \\
& +\mu_{i}(\mathbf{1})
\end{aligned}
$$

EDUC_EXP ${ }_{i}$ adalah variabel terikat yaitu pengeluaran pendidikan anak ke-i, sedangkan STATUS ${ }_{i}$ adalah variabel dummy yang menentukan apakah anak ke-i adalah berstatus kandung atau angkat. Variabel-variabel lain termasuk dalam kelompok variabel kontrol. $\beta_{1}, \beta_{2}, \ldots, \beta_{7}$ adalah koefisien regresi atau koefisien variabel, sedangkan $\mu$ adalah faktor-faktor error.

\section{HASIL PENELITIAN DAN PEMBAHASAN}

Pada tabel 2 dibawah terlihat statistik deskriptif dari keseluruhan variabel. Dari tabel dapat diketahui bahwa rata-rata pengeluaran pendidikan dari seluruh sampel adalah Rp. 2,499,767. Sedangkan rata-rata pendapatan orang tua selama setahun adalah sebesar Rp. 27,300,000. Usia orang tua ratarata berkisar pada 40 hingga 41 tahun. Rata-rata jumlah anggota rumah tangga adalah 6 hingga 7 anggota rumah tangga. Anak-anak sekolah pada sampel ratarata menempuh perjalanan sepanjang 11 hingga 12 menit dari rumah ke sekolah.

Variabel status anak adalah dummy. Anak yang berstatus sebagai anak kandung dalam sampel penelitian ini adalah sebesar 3,621 orang, sedangkan sisanya sebesar 99 orang atau $2.66 \%$ dari sampel adalah anak angkat. Variabel pendidikan orang tua juga berbentuk dummy. Orang tua yang berpendidikan tinggi setara level universitas (Diploma - S3) adalah sebesar 529 orang atau $14.22 \%$, sementara sisanya memiliki pendidikan dibawah universitas sebesar 3,191 orang. Variabel dummy lainnya adalah status sekolah. Anak yang bersekolah di SD negeri adalah sebesar 3,312 orang atau sebesar $89.03 \%$ sementara $10.97 \%$ lainnya bersekolah di SD swasta. 
Tabel 2. Statistik Deskriptif

\begin{tabular}{lcccc}
\hline \multicolumn{1}{c}{ Variabel } & Mean & Std. Dev. & Min & Max \\
\hline EDUC_EXP & 2499767 & 8106774 & 9000 & $1.003+08$ \\
STATUS & 0.9733871 & 0.1609709 & 0 & 1 \\
HEAD_INCOME & $2.73 \mathrm{e}+07$ & $4.38 \mathrm{e}+07$ & 48000 & $1.00 \mathrm{e}+09$ \\
HEAD_EDUC & 0.1422043 & 0.3493065 & 0 & 1 \\
HEAD_AGE & 40.38602 & 6.96385 & 21 & 74 \\
JART & 6.165591 & 2.802545 & 2 & 38 \\
SCHOOL & 0.8903226 & 2.802545 & 0 & 1 \\
JARAK & 11.85549 & 32.65501 & 1 & 1200 \\
\hline
\end{tabular}

Pada tabel 3 dibawah terlihat hasil estimasi model dengan metode regresi linear berganda dengan estimasi OLS. Untuk memastikan ketangguhan model, maka dilakukan robustness check berdasarkan persamaan (1). Persamaan (1) kemudian dibagi kedalam tiga model estimasi. Estimasi 1 berisi regresi antara variabel bebas utama yaitu status anak terhadap pengeluaran pendidikan. Pada estimasi 2, variabel kontrol karakteristik orang tua dimasukkan ke dalam estimasi. Yang terakhir. Pada estimasi 3 seluruh variabel kontrol termasuk jumlah anggota rumah tangga, jenis sekolah dan jarak dari rumah ke sekolah diestimasi.

Tabel 3. Hasil Estimasi OLS

\begin{tabular}{|c|c|c|c|}
\hline \multirow{2}{*}{ Variabel } & \multicolumn{3}{|c|}{ EDUC_EXP } \\
\hline & (1) & $(2)$ & (3) \\
\hline STATUS & $\begin{array}{c}-2196034 * * * \\
(825149.8)\end{array}$ & $\begin{array}{c}-2316235 * * * \\
(817398.9)\end{array}$ & $\begin{array}{c}-2484685 * * * \\
(798394.4)\end{array}$ \\
\hline HEAD_INCOME & & $\begin{array}{c}0.0206089 * * * \\
(0.0031534)\end{array}$ & $\begin{array}{c}0.0176812 * * * \\
(0.0031069)\end{array}$ \\
\hline HEAD_EDUC & & $\begin{array}{c}1267115^{* * * *} \\
(395580)\end{array}$ & $\begin{array}{c}828796.7 * * \\
(393722)\end{array}$ \\
\hline HEAD_AGE & & $\begin{array}{l}32189.85^{*} \\
(18909.44)\end{array}$ & $\begin{array}{c}40556.33^{* *} \\
(19112.42)\end{array}$ \\
\hline JART & & & $\begin{array}{l}-53099.15 \\
(47535.38)\end{array}$ \\
\hline SCHOOL & & & $\begin{array}{c}-2612940 * * * \\
(428268.2)\end{array}$ \\
\hline JARAK & & & $\begin{array}{l}-13.15389 \\
(3936.435)\end{array}$ \\
\hline Prob $>F$ & 0.0078 & 0.0000 & 0.0000 \\
\hline R-squared & 0.0019 & 0.0218 & $\mathbf{0 . 0 3 2 7}$ \\
\hline $\begin{array}{l}\text { Catatan: Angka } \\
\text { regresi berada di at } \\
\text { variabel bebas ter } \\
\text { secara statistik tida }\end{array}$ & $\begin{array}{l}\text { erada di dala1 } \\
\text { dar eror. Tand } \\
\text { variabel terik } \\
\text { ikan tanda bin }\end{array}$ & $\begin{array}{l}\text { ung adalah sta } \\
\text { ang menunjukk } \\
\text { aka variabel ya } \\
* \text { p }<0,1, * * \text { p }<0\end{array}$ & $\begin{array}{l}\text { eror. Koefisien } \\
\text { gnifikansi setiap } \\
\text { tidak signifikan } \\
* * * \text { p }<0,01 .\end{array}$ \\
\hline
\end{tabular}

Dengan mengubah notasi beta pada persamaan (1), maka berdasarkan hasil estimasi diatas, model persamaan penelitian yang terbentuk adalah sebagai berikut:

\begin{tabular}{ccccc} 
EDUC_EXP & 5307606 & - & $2484685 * S T A T U S_{i}$ & + \\
$0.0176812 * \bar{H} E A D_{-} I N C O M E_{i}$ & + & $828796.7 * H E A D \_E D U C_{i}$ & + \\
$40556.33 * H E A D \_A G E_{i}-$ & $53099.15 * J A R T_{i}$ & $-2612940 * S C H O O L_{i}$ & - \\
$13.15389 * D I S T A N C E_{i}+\mu_{i}$ & $\mathbf{( 2 )}$ & & & \\
\hline
\end{tabular}


Berdasarkan hasil estimasi OLS pada tabel 3 di atas, model persamaan penelitian ini dapat dinyatakan tangguh karena nilai R-squared meningkat seiring semakin kompleksnya suatu model. Ditambah lagi setiap penambahan variabel penjelas semakin meningkatkan koefisien variabel utama, yaitu STATUS. Variabel utama juga mampu mempertahankan signifikansi statistiknya pada tingkat kepercayaan sebesar $99 \%$.

Berdasarkan hasil estimasi didapatkan koefisien yang negatif. Artinya anak yang berstatus anak angkat memiliki pengeluaran untuk pendidikan yang lebih tinggi dibandingkan anak kandung. Perbedaan besaran pengeluaran pendidikan tersebut tercermin dari besaran koefisiennya. Pada model 3 yang memperhitungkan seluruh variabel bebas, anak angkat mendapatkan biaya pendidikan sebesar Rp. 2,484,685 lebih besar dibandingkan anak kandung selama faktor-faktor lain diasumsikan tidak berubah atau ceteris paribus.

Hasil ini sejalan dengan hasil studi dari Hamilton et al. (2007) dimana anak angkat justru mendapatkan investasi yang lebih besar dari orang tuanya dibandingkan dengan anak kandung. Hal ini dapat terjadi karena orang tua yang mengangkat anak memiliki perasaan ingin melampiaskan rasa rindu akan kehadiran buah hati. Maka ia akan memberikan investasi yang terbaik bagi anak angkatnya tersebut, khususnya dalam hal pendidikan. Ditambah lagi beban moral yang muncul ketika mengangkat anak. Apabila orang tua tersebut dalam keadaan tidak mampu memenuhi kebutuhan anak, maka mereka tidak akan dinyatakan memenuhi syarat sebagai orang tua angkat. Selain bukti dari hasil penelitian terdahulu, fakta-fakta tersebut dapat memperkuat alasan dari hasil estimasi dalam penelitian ini.

Selain menginterpretasi variabel utama, penelitian ini juga akan menginterpretasi variabel penjelas kontrol. pendapatan orang tua memiliki koefisien positif. Artinya, setiap kenaikan Rp. 1 pendapatan akan meningkatkan pengeluaran pendidikan sebesar Rp. 0.017. Dengan memperbesar skalanya, setiap kenaikan Rp. 1,000,000 pendapatan akan meningkatkan pengeluaran pendidikan sebesar Rp. 17,681. Hasil ini bukan hanya sesuai dengan teori Engel yang menyatakan bahwa pendapatan berpengaruh positif terhadap pengeluaran, juga sesuai dengan penelitian terdahulu yang menyatakan bahwa pendapatan signifikan dalam mempengaruhi besaran biaya pendidikan yang akan dikeluarkan (Acar et al., 2016; Song \& Zhou, 2019).

Meskipun variabel pendapatan berpengaruh signifikan, namun hubungannya tidak elastis (inelastic). Untuk melihat elastisitas, penelitian ini mentransformasi bentuk variabel pengeluaran pendidikan dan pendapatan orang tua yang semula nominal menjadi logaritma natural (ln). Hasilnya menunjukkan bahwa setiap kenaikan $1 \%$ pendapatan orang tua hanya meningkatkan pengeluaran pendidikan sebesar $0.29 \%$, maka dikatakan hubungannya tidak elastis. Dikatakan elastis apabila persentase perubahan pengeluaran pendidikan lebih besar daripada persentase perubahan pendapatan orang tua.

Variabel lain yang menarik untuk diamati adalah pendidikan orang tua. Secara logis kita percaya bahwa orang tua dengan pendidikan tinggi pasti menginginkan anaknya juga untuk mengenyam pendidikan yang sama dengan 
dirinya, maka pengeluaran untuk pendidikan pun akan lebih besar di kalangan orang tua yang berpendidikan tinggi. Hasil estimasi dalam penelitian ini juga mendukung pendapat tersebut. Orang tua yang memiliki pendidikan setingkat universitas (D1-S3) memberikan biaya pendidikan kepada anaknya Rp. 828,796 lebih besar dibandingkan dengan orang tua yang tidak berpendidikan tinggi. Hasil ini juga sejalan dengan penelitian-penelitian terdahulu yang menyatakan demikian (Chi \& QIan, 2016; Khalili et al., 2020; Wuryandari, 2015).

Variabel usia orang tua berpengaruh positif terhadap pengeluaran pendidikan. Bertambahnya usia orang tua sebanyak satu tahun akan meningkatkan pengeluaran biaya pendidikan anak sebesar Rp. 40,556. Penelitian terdahulu menyatakan sebaliknya, yaitu usia orang tua baik ayah dan ibu tidak berpengaruh terhadap pengeluaran biaya pendidikan anak (Khalili et al., 2020). Perbedaan hasil ini disebabkan karena struktur sampel yang berbeda. Rata-rata usia orang tua pada sampel yang digunakan penelitian terdahulu berkisar pada 45-46 tahun, sementara penelitian ini menggunakan sampel dengan rata-rata usia orang tua 40 tahun. Semakin tua seseorang akan mengalami penurunan produktivitas yang akan menurunkan pendapatannya.

Variabel jumlah anggota rumah tangga dan jarak dari rumah ke sekolah tidak terbukti signifikan mempengaruhi pengeluaran biaya pendidikan. Karena kontribusinya dianggap kecil maka kedua variabel ini tidak diinterpretasikan lebih lanjut.

\section{SIMPULAN}

Penelitian ini mendapatkan hasil yang berbeda dengan stigma yang berkembang di masyarakat yang mengatakan bahwa anak kandung lebih disayang dan diunggulkan oleh orang tuanya. Hasil penelitian ini justru mengatakan sebaliknya, dimana pengeluaran atau investasi orang tua khususnya dalam hal pendidikan justru lebih besar diberikan kepada anak angkatnya. Hal ini dapat disebabkan karena keinginan yang sangat mendalam dari orang tua untuk memiliki anak dalam kehidupan rumah tangga mereka. Namun, sayangnya mereka belum diberikan kesempatan untuk memiliki anak kandung. Maka, rasa sayang mereka tercurahkan sepenuhnya kepada anak yang mereka angkat.

Secara statistik variabel pendapatan orang tua, pendidikan orang tua, usia orang tua dan jenis sekolah (swasta atau negeri) mempengaruhi signifikan besaran pengeluaran biaya pendidikan anak. Sebagaimana yang telah diuraikan di pendahuluan, anak kandung dan anak angkat memiliki hak yang sama di mata hukum. Keduanya pantas mendapatkan hak yang setara, termasuk salah satunya adalah pendidikan. Pemerintah sudah mengatur perkara pengangkatan anak dalam peraturan pemerintah tahun 2007 silam. Didalamnya terdapat aturan serta ketentuan dalam mengangkat anak dan hal tersebut bukan dilakukan secara sembarangan. Namun pada prakteknya masih banyak ditemui kasus-kasus pengangkatan anak yang tidak dilakukan berdasarkan peraturan tersebut.

Penelitian ini mengimbau pemerintah agar memperkuat penegakan aturan tentang pengangkatan anak yang telah dibuat tersebut. Apabila pengangkatan 
anak dilakukan dengan syarat dan ketentuan yang telah distandarisasi maka anak angkat tersebut akan mendapatkan kehidupan yang laik dan sejahtera, sebaliknya apabila anak tersebut diangkat tanpa dasar yang kuat, besar kemungkinan terjadinya penelantaran oleh orang tua.

Penelitian ini masih memiliki banyak kekurangan. Untuk penelitian berikutnya disarankan tidak hanya meneliti determinan biaya pendidikan, namun juga perbedaan prestasi pendidikan antara anak kandung dan anak angkat di Indonesia.

\section{DAFTAR RUJUKAN}

Acar, E. O., Gunalp, B., \& Cilasun, S. M. (2016). An empirical analysis of household education expenditures in Turkey. International Journal of Educational Development, 51, 23-35. https://doi.org/ 10.1016/j.ijedudev. 2016.03.007

Al-Samarrai, S., \& Peasgood, T. (1998). Educational Attainments and Household Characteristics in Tanzania. Economics of Education Review, 17(4), 395-417. https://doi.org/10.1016/S0272-7757(97) 00052-6

Becker, G. S. (1993). Human Capital and The Family. In HUMAN CAPITAL A Theoretical and Empirical Analysis with Special Reference to Education (3rd ed., pp. 21-23). The University of Chicago Press.

Chi, W., \& QIan, X. (2016). Human capital investment in children: An empirical study of household child education expenditure in China, 2007 and 2011. China Ecnomic Review, 37, 52-65. https://doi.org/ 10.1016/j.chieco.2015.11.008

Hamilton, L., Cheng, S., \& Powell, B. (2007). Adoptive Parents, Adaptive Parents: Evaluating the Importance of Biological Ties for Parental Investment. American Sociological Review, 72(1), 95-116. https://doi.org/ 10.1177/000312240707200105

Heriawan, M. (2017). Pengangkatan Anak Secara Langsung dalam Perspektif Perlindungan Anak. Jurnal Katalogis, 5(5), 175-179.

Iddrisu, A. M., Danquah, M., \& Quartey, P. (2017). Paying for Education among Household in Ghana: Is There Any Role for Household Resouces and Contextual Effects? International Journal of Development Issues, 16(2), 214-226. https://doi.org/10.1108/IJDI-02-2017-0017

Khalili, N., Arshad, M., Farajzadeh, Z., Kachele, H., \& Muller, K. (2020). Effect of drought on smallholder education expenditures in rural Iran: Implications for policy. Journal of Environmental Management, 260. https://doi.org/10.1016/j.jenvman.2020.110136 
Kousar, R., Sadaf, T., Makhdum, M. S. A., \& Ijaz, A. (2017). Determinants of Household's Education and Nutrition Spending: A Gender-based Empirical Analysis. Humanomics, 33(4), 470-483. https://doi.org/ 10.1108/H-06-2016-0050

Liu, J., Wyshak, G., \& Larsen, U. (2004). Physical well-being and school enrollment: a comparison of adopted and biological children in one-child families in China. Social Science \& Medicine, 59, 609-623. https://doi.org/10.1016/j.socscimed.2003.11.008

Maulana, R. (2020). Apakah Pendidikan Tinggi Meningkatkan Kemungkinan untuk Bekerja di Sektor Formal?: Bukti dari Data SAKERNAS. Jurnal Ekonomi Kuantitatif Terapan, 1(1), 133-144. https://doi.org/10.24843/ JEKT.2020.v13.i01.p06

Mutasir, M. (2017). Dampak Hukum Pengangkatan Anak pada Masyarakat Desa Terantang Kec. Tambang Kabupaten Kampar Ditinjau dari Hukum Islam. An-Nida': Jurnal Pemikiran Islam, 41(2), 173-192.

Raleigh, E., \& Kao, G. (2013). Is there a (transracial) adoption achievement gap? A national longitudinal analysis of adopted children's educational performance. Children and Youth Services Review, 35, 142-150. https://doi.org/10.1016/j.childyouth.2012.09.019

Reza, F., \& Widodo, T. (2013). The Impact of Education on Economic Growth in Indonesia. Journal of Indonesian Economy and Business, 28(1), 23 44.

Song, Y., \& Zhou, G. (2019). Inequality of opportunity and household education expenditures: Evidence from panel data in China. China Economic Review, 55, 85-98. https://doi.org/10.1016/ j.chieco. 2019.03.002

Wardah, W. (2011). Perlindungan Hukum Internasional terhadap Pelaksanaan Adopsi Anak Antar Negara. Kanun Jurnal Ilmu Hukum, 13(2), 133-142.

Widyaningsih, E., \& Muflikhati, I. (2015). Alokasi Pengeluaran dan Tingkat Kesejahteraan Keluarga pada Keluarga Nelayan Bagan. Jurnal Ilmu Keluarga Dan Konsumen, 8(3), 182-192. https://doi.org/10.24156/ jikk.2015.8.3.182

Wuryandari, R. D. (2015). Faktor-faktor yang Memengaruhi Pengeluaran Makanan, Pendidikan, dan Kesehatan Rumah Tangga Indonesia (Analisis Data Susenas 2011). Jurnal Kependudukan Indonesia, 10(1), 27-42. 
